\title{
RESEARCH PAPER \\ STAFF DEVELOPMENT OF LIBRARY ASSISTANTS IN THE KWAME NKRUMAH UNIVERSITY OF SCIENCE AND TECHNOLOGY, KUMASI, GHANA
}

\author{
E. M. Borteye and Michael Ahenkorah-Marfo \\ University Library, KNUST, Kumasi
}

\begin{abstract}
The study utilized the questionnaire instrument to collect and analyze data to determine the state of staff development of Library Assistants in the Kwame Nkrumah University of Science and Technology. All Library Assistants were taken through staff orientation and on the job training. They also received instruction in user/reader services. Over 89\% of the Library Assistants were satisfied with the in-service training given. Only $29 \%$ of them had enjoyed study leave with pay, while over 55\% were desirous to be granted study leave to pursue further studies in Library and Information related programmes. It was revealed that most Library Assistants did not have the opportunity to participate in seminars, workshops, Library Association Meetings and Conferences. Recommendations have therefore been given to correct these anomalies.
\end{abstract}

Keywords: Librarianship, Paraprofessionals, Training, University Libraries

\section{INTRODUCTION}

The library system generally consists of three main types of workers. These are the professional staff, paraprofessionals and those without any formal training in librarianship. The last two categories have severally been described in the library world as support staff, paraprofessionals, sub-professionals, nonprofessionals, library assistants, etc (Oguntabi and Bantai, 1999; Wijetunge, 2001).

Jennerich (2006) indicates that library assistants "are an inseparable part of the total workforce of the library and need to be developed for both their own needs as well as for the library's goals within the university set up".

Antwi and Nwali (1990) quoting Piper defined staff development as a "systematic attempt to harmonize the individual's interest and wishes, his carefully assessed requirements for furthering his career and the forthcoming requirements of the organization within which he is expected to work".

All organizations are different and have different needs, goals, objectives and even cultural values. It is therefore not surprising that Jene- 


\section{Borteye and Ahenkorah-Marfo}

rich (2006) states that if a library wants to ensure that it gets value for money and results are measurable then it is vital that it demonstrates commitment by providing staff with a clear direction. He continues that a library should consider the benefits of having a workforce plan, a staff development methodology, and have an understanding of the key competencies required by staff.

One of the most important things to realize as a library finds its way toward a defined, strategic plan of staff development is that no organization's culture can be changed overnight. Taking the long-term view, Jennerich (2006) advised that "the effects of a staff development and training programme are gradual and will only happen with sustained efforts and consistent attention. It is tempting to deliver short, intense blasts of training aimed at organizational problems or a group of employees. Patience, persistence and repetition, however, are the keys to engineering change and unlocking the potential within library staff members".

Cossham and Fields (2007) assert that, in practice, the choice of what continuing professional development (CPD) an individual needs and wants has to take into consideration the requirements of their current position and current employer, their own development and growth needs, plus the changing nature of the work.

The question to be answered is what training programmes- formal and informal- has the KNUST Library made available to these categories of staff and the extent to which the staff have availed themselves of the programmes.

Staff development over the years in the KNUST Library System has taken the form of staff orientations, in-service training, seminars, library use instruction, staff meetings and study leave for formal education in library studies.

This study is limited to library assistants in the KNUST Library System. It is aimed at;

1. Finding the staff development programmes available in the KNUST Library System for library assistants.

2. Determining the extent to which staff have availed themselves of the programmes

3. Making recommendations to improve on the existing situation.

In his earlier work on professional staff development in the KNUST Library, Osei (1996) noted that constraints such as finance and time were among the many problems militating against professional staff development. Adanu (2007) corroborates this with the assertion that the greatest barrier to CPD of professional librarians in state-owned university libraries in Ghana is lack of financial assistance from the libraries or institutions. Though Osei and Adanu's studies were good they focused only on professional staff. No study has been done in respect of library assistants who constitute the largest portion of the Library's workforce, hence the need for this study.

\section{METHODOLOGY}

The main data collection instrument adopted for this study was the questionnaire. Data for this study were collected in the month of April 2010 by the authors. The questions were closeended and required a yes or no or one response from a checklist of possible replies. The questions sought information in areas such as gender, age, educational background, work experience in the library, rank, whether respondents had any form of training since they were appointed, satisfaction with the training, usefulness of the training among others. Respondents were asked to tick, circle or underline the most appropriate option(s).

The census technique was employed to collect data for the study. This was mainly because the population was relatively small. The authors therefore deemed it appropriate to cover the entire population of the library assistants. A study in which a researcher attempts to collect data on each member of the population is known as a census (Gericke et al, 1996). 
In all 70 copies of the questionnaire were sent out to solicit data for this study. Out of the total, 58 copies of the questionnaire representing approximately $82 \%$ were returned for analysis. This analysis is therefore based on the responses from the 58 copies of questionnaire received from the respondents.

The Statistical Package for the Social Sciences (SPSS) was used for the analysis. Descriptive statistics were used to summarize the data. The data were presented in percentages using simple tables.

\section{RESULTS AND DISCUSSION \\ Age of respondents}

Table 1 below illustrates the statistics of the age of the respondents for the study. Those who are between the ages of 20 to 30 years dominated with $37.9 \%$. This was followed by those between the ages of $31-40$ with a percentage of 34.5. A large number of the Library's workforce (Library Assistants) as the table shows are below the age of 40 . Only $12.1 \%$ of this category of workforce is nearing the age of compulsory retirement and this is healthy for the Library.

\section{Educational background}

Table 2 presents statistics of the educational background of the Library Assistants working in the KNUST Library system. As illustrated in the table those with secondary education were 39 representing $67.2 \%$ of the population.

Table 1: Age of respondents

\begin{tabular}{lcl}
\hline Age & Frequency & Percentage \\
\hline $20-30$ & 22 & 37.9 \\
$31-40$ & 20 & 34.5 \\
$41-50$ & 9 & 15.5 \\
$51-60$ & 7 & 12.1 \\
Total & 58 & 100 \\
\hline
\end{tabular}

Source: KNUST Library, 2010
Staff development of Library Assistants ... 107

Those with diploma were 13 representing $22.4 \%$. Bachelor's degree holders were 4 representing $6.9 \%$. The table indicates that a large proportion of the Library Assistants had secondary school education background with only a few having diplomas and bachelor degrees. This also means that many of the Library Assistants of the Library were yet to obtain a formal qualification in librarianship. This situation calls for intensified in-service training in order to manage the Library efficiently.

\section{Designation of respondents}

Table 3 shows the statistics of the ranks of the respondents. As the table shows, those in the category of Junior Library Assistant had the highest frequency of 41, representing $70.6 \%$. Library Assistant rank recorded 13.8\%. Senior Library Assistant, Principal Library Assistant, Chief Library Assistant and Senior Technicians recorded 5.2, 5.2, 3.4 and 1.7 percent respectively. The statistics show that a greater part of the Library's workforce was currently in the Junior Library Assistant category. This group needs to upgrade their skills through further studies so that they can be promoted to senior rank positions to assume the mantle of leadership in the Library through continuous education.

\section{Professional Experience}

The length of time respondents had worked in the library was considered very important to this study. This is because the more experienced respondents were the better they would be in a position to give accurate picture of staff development in the Library. The respondents were therefore asked to indicate the number of years that they had worked in the Library. Table 4 below summarizes the number of years that each of the respondents had worked in the Library. From table 4 Library Assistants who had worked in the Library between one and five years had the highest response rate of $46.6 \%$. It was observed that there was a high turnover of the Junior Assistant category who constituted majority of the Library staff. This is mainly because many of the Junior Library Assistants 


\section{Borteye and Ahenkorah-Marfo}

only use the Library as a stepping stone. Some even turned down the opportunity to pursue Diploma in librarianship run by the Department of Library Studies in the University of Ghana, Legon. Others were interested in pursuing programmes such as Teacher Training, Nurses' Training and other degree programmes. All that such assistants did was to work whilst waiting to gain admission to their preferred progra- mmes. This implies that the library always has to embark on in-service training to upgrade the skills of newly recruited staff of this category as the trained ones leave for further studies. The responses can be seen in table 4 below.

\section{In-service training}

One of the essential things that institutions must consider is the continuous training of their

Table 2: Educational background of respondents

\begin{tabular}{lll}
\hline Educational background & Frequency & Percentage \\
\hline Secondary education & 39 & 67.2 \\
Diploma & 13 & 22.4 \\
Bachelors & 4 & 6.9 \\
Masters & 1 & 1.7 \\
No response & 1 & 1.7 \\
Total & 58 & 100 \\
\hline
\end{tabular}

Source: KNUST Library, 2010

Table 3: Ranks of the respondents

\begin{tabular}{lcl}
\hline Designation & Frequency & Percentage \\
\hline Junior Library Assistant & 41 & 70.6 \\
Library Assistant & 8 & 13.8 \\
Senior Library Assistant & 3 & 5.2 \\
Principal Library Assistant & 3 & 5.2 \\
Chief Library Assistant & 2 & 3.5 \\
Senior Technician & 1 & 1.7 \\
Total & 58 & 100 \\
\hline
\end{tabular}

Source: KNUST Library, 2010

Table 4: Professional experience of respondents

\begin{tabular}{lcc}
\hline Professional experience & Frequency & Percentage \\
\hline Less than 1 year & 4 & 6.9 \\
1-5 years & 27 & 46.6 \\
5-10 years & 8 & 13.8 \\
More than 10 years & 18 & 31 \\
No response & 1 & 1.7 \\
Total & 58 & 100 \\
\hline
\end{tabular}

Source: KNUST Library, 2010 
their staff. This will ensure that the members of staff are well equipped to go about their duties daily without difficulties. In-service training for staff according to Antwi and Nwali (1990) is done with the view to achieving greater productivity. This question therefore sought to know from the respondents if the Library provided Library Assistants with in-service training. There was overwhelming response to this question. All the respondents answered in the affirmative. This is a positive development as those who have not had the opportunity to go for further studies were given the needed skills to go about their daily duties without difficulties.

\section{Type of in-service training}

There are several forms of training available to staff. For example staff orientation, instruction in shelving, instruction in reader services and others are usually organized for newly employed and sometimes those already on the job to upgrade their skills so that they can perform efficiently on the job. The intent here was to find out from the respondents the kind of training they had received since their appointment.

Table 5 illustrates their responses to this question. Those who mentioned orientation on appointment and staff meetings as the forms of training they received dominated with a percentage of 51.7. Those who received on the job training as the only form of training recorded the lowest percentage of 10.3. The percentages for the other responses can be seen in table 5 . The reason that accounts for the overwhelming response given to orientation on appointment and staff meetings is that all staff meetings and orientation on appointment are mandatory. It is also worthy of note that all the respondents mentioned that they had received one form of training or the other.

Respondents were further asked to indicate the extent of their satisfaction with the training they received. Their responses are presented in table 6. As can be seen in the table those who stated that they were satisfied with the training provided recorded a percentage of 43.1. This was followed by those who stated that they were very satisfied. A non response rate of $10.3 \%$ was recorded for this question. Cumulatively $89.7 \%$ of the respondents had varying degrees of satisfaction with the training they received. The general satisfaction shown by respondents suggests that the in-service training programmes met their needs.

\section{Frequency and usefulness of in-service train- ing}

Table 7 below shows the responses given by the respondents regarding the frequency of the in-service training programmes. As can be seen in the table those who mentioned 'others' as their answer to this question had the highest frequency of 34 representing 58.6\%. Some of the answers they gave for mentioning 'others' are as follows; 'once in a blue moon', 'as and when it is needed', 'once a while' among others. Sixteen respondents, representing $27.6 \%$ indicated that the training was done annually in the Library while $8.6 \%$ did not respond. The rest of the responses are indicated in table 7 below. In-service training is organized as and when it is necessary. It is therefore not surprising for many of the respondents to mention 'others' since in-service training is not organized regularly.

Respondents were further asked to indicate whether the training provided had been useful to them. This is illustrated in table 8 . From the table it can be seen that those who stated that the training provided in the Library had been very useful to them recorded a percentage of 44.8. This was followed by those who mentioned that the training provided had been useful with a percentage of 41.4. There was a non response rate of $8.6 \%$. The results depict that training provided in the Library to the Library Assistants has been generally useful to them.

\section{Participation in Library Association Pro- grammes}

Participation in the Ghana Library Association programmes is another way of complementing 
Table 5: Type of training

\begin{tabular}{lcl}
\hline Type of training & Frequency & Percentage \\
\hline Orientation on appointment and staff meetings & 30 & 51.7 \\
Orientation on appointment, instruction in shelving and automation & & \\
workshop & 10 & 17.3 \\
Orientation on appointment, instruction in shelving, instruction in & 12 & 20.7 \\
user services and on the job training & 6 & 10.3 \\
On the job training & 58 & 100 \\
Total & & \\
\hline
\end{tabular}

Source: KNUST Library, 2010

Table 6: Level of satisfaction

\begin{tabular}{lcl}
\hline Level of satisfaction & Frequency & Percentage \\
\hline Very satisfied & 23 & 39.7 \\
Satisfied & 25 & 43.1 \\
Fairly satisfied & 4 & 6.9 \\
No response & 6 & 10.3 \\
Total & 58 & 100 \\
\hline
\end{tabular}

Source: KNUST Library, 2010

Table 7: Frequency of training

\begin{tabular}{lcl}
\hline Frequency of training & Frequency & Percentage \\
\hline Annually & 16 & 27.6 \\
Semi-annually & 2 & 3.5 \\
Monthly & 1 & 1.7 \\
Other & 34 & 58.6 \\
No response & 5 & 8.6 \\
Total & 58 & 100 \\
\hline
\end{tabular}

Source: KNUST Library, 2010

the training given to members of staff of the Library. During such programmes members are able to learn new developments in the library and information profession in general from other participants through the sharing of knowledge.

It is in pursuit of this that respondents were asked to indicate whether they had attended any Ghana Library Association meetings before. Those who said that they had not attended any Library Association meetings before constituted $58.6 \%$. Those who said they had attended such meetings before were 22 representing $37.9 \%$. There was a non response rate of $3.5 \%$. It is evident that quite a significant number of 
Staff development of Library Assistants... 111

Table 8: Usefulness of training

\begin{tabular}{lcl}
\hline Training & Frequency & Percentage \\
\hline Very useful & 26 & 44.8 \\
Useful & 24 & 41.4 \\
Fairly useful & 2 & 3.5 \\
Other & 1 & 1.7 \\
No response & 5 & 8.6 \\
Total & 58 & 100 \\
\hline
\end{tabular}

Source: KNUST Library, 2010

staff indicated that they had never attended any of such programmes organized by the Ghana Library Association. This is not surprising because such meetings and programmes are meant for only professional and paraprofessional staff. It is therefore necessary for the library administration to encourage the para -professionals category of the Library Assistants to take advantage of such programmes. This is because the junior category of the library assistants are not qualified members of the Ghana Library Association.

\section{Study leave plans for Library Assistants}

Respondents were asked to indicate if they had been on study leave before. Those who said that they had not been on study leave before were 42 representing $72.4 \%$. Those who had gone on study leave before were 15 representing $27.6 \%$. This shows that a greater proportion of the library's workforce were yet to upgrade their skills professionally through formal education in the library school. The Library has a policy and schedule for study leave which all library assistants follow. This is to make sure that there is always an adequate number of staff at post for effective service delivery. Study leave is largely based on the Library's needs. What this means is that the KNUST administration would only grant study leave (with pay) to Library Assistants who are prepared to pursue programmes in librarianship or related disciplines, such as Book Industry and Computer Science.
A sequel to this question sought to know from the respondents especially those who had been on study leave before if they were on study leave with pay. Only 16 respondents representing $27.6 \%$ responded in the affirmative. The others representing $72.4 \%$ declined to answer this question.

\section{Further education}

Respondents were asked to indicate whether they intend to go for further education. Those who indicated that they intend to further their education were 39 representing $67.2 \%$ with as little as $5.2 \%$ indicating that they did not intend to go for further studies. It can be inferred from the responses that a greater number of the respondents intend to further their education

A sequel to this question asked respondents to indicate which field they would pursue if they decided to go for further education. The responses are indicated in table 9. Those who said that they would go for librarianship recorded the highest percentage of 65.5. This was followed by those who indicated that they would opt for any information related career with a frequency of 12 representing $20.7 \%$. The rest of the responses are presented in table 9 below. Several of those who chose librarianship explained further that they have come to love the profession and so the best thing for them to do was to continue with it. This sounds very encouraging, so steps should be taken by the staff involved and the library management to 


\section{Borteye and Ahenkorah-Marfo}

ensure that their desires were achieved, especially when most of them indicated their desire to pursue library related programmes.

It must however be noted that job security may account for some of the respondents deciding to pursue librarianship even though they failed to state that. It is most likely that many would have sincerely mentioned professions other than librarianship. Some of those who opted to pursue other information related career indicated that not everyone can travel to Accra to pursue librarianship at the University of Ghana, Legon, the only institution in Ghana that offers that programme. Such respondents mentioned that they could also go in for Publishing Studies which is also related to the information profession, which is offered on KNUST campus. A few of them also mentioned Computer Science and Information Technology programmes as some of the careers they would like to pursue. This is also another positive development because majority of the Library Assistants expressed interest in further education as a means of upgrading their knowledge and skills. This shows that the future of the Library is very bright.

\section{CONCLUSION}

This study was embarked upon to find out the training programmes available for Library Assistants in the KNUST Library System. The study discovered that training programmes exist for all Library Assistants. The training programmes include staff orientation on appointment, instruction in user-services and instruction in shelving among others. All Library
Assistants had benefited from one or two of the training programmes available. Again, a greater proportion of the Library Assistants had not gone on study leave before. Besides, many of the respondents as this study has shown do not have professional or even para-professional qualification in librarianship. Most of them expressed their willingness to further their education in librarianship or in any information related programmes so that they will become information professionals. It is believed that the findings and recommendations of this study can provide lessons for other university libraries in Africa.

\section{RECOMMENDATIONS}

In the light of the foregoing, the following recommendations are being made;

It is recommended that the Library takes a second look at the training programmes organized in the Library in terms of the frequency and content. Some programmes like instruction in filing and shelving could be organized annually since they have direct impact on the retrieval of the Library's resources.

All Library Assistants should be encouraged and allowed to partake in the seminars and workshops organized in the Library for senior members.

Again, all senior staff category of the Library Assistants should be encouraged to take part in Library Association meetings, seminars, workshops and conferences. This will whip up their enthusiasm to go for further studies in librar-

\begin{tabular}{lll}
\hline Career & Frequency & Percentage \\
\hline Librarianship & 38 & 65.5 \\
Any information related career & 12 & 20.7 \\
Other & 2 & 3.5 \\
No response & 6 & 10.3 \\
Total & 58 & 100 \\
\hline
\end{tabular}

Source: KNUST Library, 2010 
Staff development of Library Assistants... 113

ianship.

Library Assistants should be encouraged to take advantage of the various distance learning education programmes in Ghana and elsewhere rather than joining the queue for study leave with pay. Attempts should be made by the Library to encourage especially those who for some reasons cannot do a campus based programme to consider distance learning as an option to upgrade their knowledge and skills.

Above all a well developed library service training manual could be a big boost for selfhelp to Library Assistants.

\section{REFERENCES}

Adanu T. S. A. (2007). The knowledge and practice of continuing professional development among professional librarians in stateowned university libraries in Ghana, Ghana Library Journal, 19:1-19

Antwi, I. K. and Nwali, L. O. (1990). Staff development of librarians: the case of the Abubakar Tafawa Balewa University Library, Nigeria, Library Management, 11 (6):30-34

Cossham, A. and Fields, A. (2007). Balancing individuals' expectations and organizational requirements for continuing professional development, Library Review, 56(7): 575576

Gericke, E. M., Fourie, J. A., Machet, M. P., Meyer, H. M. and van der Walt, T. B. (1996). Aspects of user studies: only study guide for HINKGE-8, Pretoria: University of South Africa, p.232

Jennerich, E. Z. (2006). The long-term view of library staff development, College \& Research Libraries News, 67(10):612-614

Oguntabi, S. A. and Bantai, R. C. (1999). Appraising staffing pattern in a Nigerian university library, 1981-1997, Library Career Development, $7(8): 77-84$

Osei, I. (1996). Professional staff development in academic libraries: the case of University of Science and Technology Library, Kumasi, Librarian Career Development, 4(4):31-36

Wijetunge, P. (2001). Training and Education of Paraprofessionals in Sri Lankan University Libraries, Journal of Education for Library and Information Science, 42(2):150 